\title{
Manden eller bolden? Om værdier, politik og deliberativt demokrati
}

Jørn Loftager Lektor, Institut for Statskundskab, Århus Universitet

Er værdipolitik egentlig et nyt fænomen, som mange påstår? Er den politiske værdidiskurs og fokus på identitet fremmende for den politiske debat eller det modsatte? Følgende artikel behandler disse spørgsmål på baggrund af klassisk sociologisk teori og teorien om det deliberative demokrati.

Politik er ikke er, hvad politik har været. Og for så vidt, historien bevæger sig, er det en triviel konstatering. Men måske vi i disse år og årtier er vidner til særligt gennemgribende ændringer af det politiske? Det synes i det mindste at være en udbredt opfattelse i forskerverdenen, bl.a. indikeret af bogtitler fra det danske valgprojekt som 'Politisk forandring' (Goul Andersen \& Borre 2003) og 'Det nye politiske landskab' (Goul Andersen m.fl. 2007). Men også blandt meningsdannere og kommentatorer og vel i offentligheden generelt har den samme opfattelse bredt sig. Hvordan det nye nærmere skal benævnes, tolkes og begrebsliggøres står ikke klart, men bortset fra den neutrale og i sig selv ret intetsigende tale om "nypolitik“, har betegnelsen og begrebet „værdipolitik“ vundet almindelig indpas, og der forskes bredt i The Impact of Values (Van Deth \& Scarbrough 1998). Der kan indforstået refereres til, hvordan gammelpolitikkens typiske fordelingsspørgsmål med forbindelse til samfundets klassestruktur er blevet suppleret, hvis ikke overhalet af nypolitikken med dens fokusering på værdier, og forskningen har kunnet påvise tilstedeværelsen af to adskilte dimensioner, der strukturerer den politiske dagsorden, vælgernes holdninger og partiernes konkurrence om magten (Borre 2003).
Selv om billedet tegnet på den måde har en solid empirisk forankring, er det værd at overveje rækkevidden af dets gyldighed, og specielt finder jeg betegnelsen værdipolitik problematisk. Det skal belyses videre nedenfor, men generelt sagt kan det forekomme underligt at benævne en særlig slags politik „værdipolitik“, når der samtidig hersker udbredt enighed om at definere politik i almindelighed med henvisning til værdier (Easton 1953, 129). Nuvel, hvad betegnelsen søger at indfange er nok, at nogle nye værdier er kommet til at præge dagsordenen, hvorfor det ville være rigtigere - om end sprogligt tungt - at tale om „nyværdipolitik“. Tillige synes så meget af værdipolitikkens substans at dreje sig om identitet og identitetsdannelse, at „identitetspolitik“ kunne være at foretrække, hvilket da også sker, især i forbindelse med multikulturproblematikken.

Også figuren (gammel) fordelingspolitik contra (ny) identitetspolitik vil dog efter min mening være problematisk. Den kan fejlagtigt give det indtryk, at det er noget nyt, at politik handler om identitet, hvorved den kan bortlede opmærksomheden fra tidligere og måske nok så væsentlige identitetsspørgsmål. Endvidere er hele denne ny/gammel diskurs fokuseret på det (aktualiserede) partipolitiske spil om magten og forudsætter dermed implicit også, at det er de sider af politikken, der er de vigtigste. Men er det nødvendigvis tilfældet? Måske magten kunne have mere end et ansigt (jf. Bachrach \& Baratz 1962; Lukes 1983). Og hvordan skal man videre tolke konstaterbare mønstre i folks survey-målte værditilkendegivelser og tilhørende partivalg? Gør forskellene mellem partierne, som de kan placeres på værdilandkortet tilsvarende forskel på et praktisk policyplan? Eller: „Hvor stor er forskellen egentlig 
mellem DF og SF“, som en avisartikel på begrundet vis spurgte om for nylig (Jyllandsposten 12-08-09). Kan forskellene med hensyn til samfundsmæssig betydning og rækkevidde sidestilles med tidligere tiders skillelinjer?

Forudsætningen for at blive klogere på den slags spørgsmål er en artikuleret makroteori, der kan tjene som ramme for begribelsen af de empiriske iagttagelser. Uden en sådan teori mangler man grundlaget for at vurdere betydningen af de konstaterede fænomener og sammenhænge og herunder, om de er som forventet, eller om de overrasker, og om der derfor er noget at undre sig over $^{1}$. Sigtet med denne artikel er at gøre opmærksom herpå, og baggrunden er, at der forekommer mig at være tungtvejende såvel politisk-sociologiske som demokratiske grunde til faktisk at undre sig over den måde, politikken udspiller sig på. Ikke mindst kan det undre, at (nye) værdi- og identitetsspørgsmål, hvor det synes at handle om „manden snarere end bolden“, er kommet til at fylde så meget. Det skulle hverken forventes ud fra klassisk sociologisk teori eller almindeligt anerkendte demokratiske idealer. Og i stedet for straks at forkaste teorien og idealerne i lyset af de uventede kendsgerninger, er der grund til at overveje disse kendsgerningernes status som kendsgerninger. Måske de kan forklares som andet end blot positivt foreliggende nødvendigheder, og eventuelt kan de også tilskrives en bestemt diskurs, som forskningen kan være med til at vedligeholde.

Med udgangspunkt i referencer til en generel teoretisk ramme, Jørgen Goul Andersen har præsenteret (Goul Andersen 2007), skal jeg skitsere et politisk-sociologisk makroperspektiv med nedslag hos John Dewey, Emile Durkheim, T.H. Marshall og Niklas Luhmann samt i teori om demokrati som deliberativt demokrati. Af dette teoriunivers fremgår en borgeridentitet, der muliggør, at politisk strid kommer til at handle om „bolden snarere end manden" - om udveksling af argumenter snarere end mobilisering af identitetsmarkører og ven-fjende konfrontationer. Først skal grunden herfor gødes gennem en påpegning af, hvordan politik må forstås som et flerdimensionelt fænomen.

\section{Aspekter af politik ${ }^{2}$}

Det nærmeste, man kommer på en alment accepteret definition af politik i statskundskaben, er utvivlsomt David Eastons ,authoritative allocation of values for a society“ (Easton 1953, 129). Definitionen er ikke uomtvistet, men den synes umulig at komme uden om, når bestemmelsen af politik som fænomen bringes til diskussion. Et aktuelt dansk eksempel herpå er Frølund Thomsens bog Politik $i$ det moderne samfund, hvor Eastons definition ofres en del opmærksomhed og også danner rygrad i Thomsens eget definitionsforslag (Thomsen 2008, 147). Resultatet er en definition, hvor politik ikke alene drejer sig om værdiers fordeling, men tillige deres dannelse og - Thomsens bidrag - institutionalisering. Altså er der tale om endnu en bekræftelse af den almindelige forestilling om en nødvendig forbindelse mellem værdier og politik. Af samme grund bliver det tilsvarende sprogligt problematisk at tale om værdipolitik som en ny og særlig form for politik. Vil det ikke svare til, at møbelfabrikanten lancerede sin nye reol under sloganet „nu med hylder"?

Som Thomsen gør opmærksom på, er det ikke ganske klart, hvad Easton forstår ved værdier (2008, 23), men med definitionens fokus på fordeling, synes det nærliggende at forbinde den med den interessepolitik, der har præget det danske politiske system gennem det 20. århundrede. Kampen om den politiske magt med henblik på at tilgodese forskellige interesser kan uden problemer dækkes ind af denne definition. Politik handler om - som en anden fremtrædende amerikansk politolog, Harold Laswell, formulerede det: „Who gets what, when and how?" (jf. Rasmussen 1971, 62). Den politiske proces anskues som en aggregeringsproces, hvor de enkelte interesser skæres til og føjes sammen i den kollektive beslutning, og demokratiet handler da typisk om at sikre, at alle interesser eller præferencer tilgodeses ligeligt (jf. nedenfor).

Ofte eller altid vil der være indbygget et konfliktperspektiv i denne grundforestilling om politikken. Drejer konflikten sig ikke alene om, hvem der får hvad, men også hvem der er hvad, fremstår en anden og særlig forståelse af det politiske, hvor identiteter og deres indbyrdes forhold kommer i centrum. Og når det i de senere år er blevet udbredt at tale om en „nypolitik“" koncentreret om „værdier“ til forskel fra "gammelpolitikken“ og dens fordelingsspørgsmål, kan det ses som et udtryk for et gennemslag af denne dimension af politikken. Indholdsmæssigt kan identitetspolitik antage vidt forskellige skikkelser. I den ene ende af spektret kan konfliktelementet accentueres så kraftigt, at forholdet mellem ven og fjende fremstår som det afgørende - det stof, politik dybest set er lavet af som hos Carl Schmitt (jf. Larsen \& Laustsen 2009). I den anden ende har den republikanske tradition lagt vægt på udviklingen af en identitet som borger med tilhørende dyder, der muliggør, at frie individer sammen kan realisere et handledygtigt fællesskab. I teorihistorien udgør Hannah Arendt her et markant eksempel (jf. Rostbøll 2009).

I sidstnævnte opfattelse er fokus ikke først og fremmest rettet mod den enes magt over den anden, men mod „magt til“ og det kollektivt „at magte“. Og det kan lede over til en tredje politikdimension. For ud over interessevaretagelse og dannelse af og konflikt mellem identiteter handler politik også om samfundsmæssig problemlosning ${ }^{3}$ Politik er også fx landbrugs-, miljø-, undervisnings- og arbejdsmarkedspolitik, og i bredere forstand drejer poli- 
tik sig om ledelsen og styringen af samfundet som samfund. Også om denne dimension af politikken er der delte meninger. For det første hersker der grundlæggende uenighed om, hvor god en problemløser politik i form af kollektivt bindende beslutninger overhovedet kan være. Stærke positioner i den politiske teori argumenterer for, at politikken - og staten - bør fylde så lidt som muligt og eventuelt helt afskaffes. På dette punkt mødes (dele af) liberalismen og marxismen på interessant vis i en vision om et post-politisk samfund (Spragens 1981; Loftager 2009). For det andet er der meget forskellige syn på, hvilken styreform der bedst kan sikre styringen og ledelsen af samfundet. Spændet går fra et styre ved dertil uddannede filosoffer (Platon) eller eksperter (teknokrati) til direkte demokrati med deltagelse af principielt alle borgere (Barber 1984).

De fleste vil kunne enes om, at politik både drejer sig om magt- og fordelingskamp, identitetsdannelse og -konflikt samt samfundsmæssig problemløsning. Uenigheden drejer sig i stedet om, hvad der udgør politikkens primare dimension. Blandt andet vil mange være af den opfattelse, at det egentlig politiske er noget andet end problemløsning, noget der føjer sig til eller lægger oven i dette aspekt. Svarende hertil kan der skelnes mellem teknik og politik, eller mellem politikkens saglige eller pragmatiske aspekter og dens egentlige politiske side, der vedrører sådan noget som værdier, interesser og identiteter og strid herom.

Heroverfor vil tilslutte mig en opfattelse, hvor netop problemløsning udgør politikkens primære aspekt. Dermed benægtes det ikke, at politik også drejer sig om interesser og identitet, og heller ikke, at der kan konstateres tendenser til, at nye værdi- og/eller identitetsmæssige spørgsmål har vundet frem i forhold til tidligere tiders dominerende interessepolitik. Men påstanden er, at såvel interessevaretagelse og identitetsdannelser som momenter i politikken bedre, mere holdbart og hensigtsmæssigt lader sig begribe i perspektiv af politik som primært problemløsning. Nærmere begrundelse vil fremgå, men synspunktet er bl.a. inspireret af Marx' betragtninger over produktionen og produktionsmådes status som primært aspekt af samfundet. I en kommentar til en anmelder, der over for hans „basis-overbygningsmodel“ kritisk refererer til, at katolicismen dog herskede i middelalderen og politikken i antikken, bemærker Marx:

Så meget er klart, at middelalderen ikke kunne leve af katolicismen og den antikke verden ikke af politikken. Tværtimod, den måde, hvorpå de skaffede sig udkommet, forklarer hvorfor politikken dér og katolicismen her spillede hovedrollen (Marx 1870-1872, 184).
Svarende hertil kunne man til interessepolitikkens - og Eastons politikdefinitions - dominans sige, at den afspejler, hvordan konfliktende (klasse)interesser faktisk udgjorde det dominerende samfundsproblem i det 20. århundrede.

\section{Teori om politikken og dens sociale funktion}

I dansk sammenhæng har Jørgen Goul Andersen (JGA) skitseret en teoretisk ramme til forståelsen og analysen af den aktuelle politik (Goul Andersen 2007). Der er tale om et både interessant og ambitiøst bidrag, som jeg inden for denne artikels rammer ikke har mulighed for at kommentere efter fortjeneste. Enkelte centrale punkter skal dog her indledningsvist berøres. Først er der grund til at bifalde følgende markering:

I modsætning til new politics er udgangspunktet her ikke værdiændringer, men de underliggende samfundsmæssige modsætninger, det handlingsrum, de skaber for politiske aktører, og den faktiske artikulering af konflikter på makroplanet (Goul Andersen 2007, 21).

Med en strukturel analyse på makroniveau undgås den cirkelslutning, der er snublende nær, såfremt man opererer med værdier og holdninger som selvstændigt givne uafhængige variable - vælgeren der stemmer socialdemokratisk på grund af socialdemokratiske værdier. I stedet indgår, siger JGA, „fast strukturerede værdier og holdninger som forbindelsesled“ (mellem struktur og adfærd) (21). Men, bliver det da ikke relevant at spørge, jf. det citerede, om givne artikulerede konflikter svarer til det forventede? Og hvis ikke, hvad så? Ja, så kan der være grund til at interessere sig for tilblivelsen og eventuelt også „rationaliteten“" af konstaterbare værdier, holdninger og/ eller identiteter i forhold til det, samfundsanalysen afdækker. Som JGA understreger, er der ikke nogen automatisk forbindelse mellem socio-strukturelle betingelser og politiske reaktioner, ligesom der ikke behøver at være nogen logisk forbindelse mellem holdninger, der i praksis måtte vise sig at hænge sammen på parti- og vælgerniveau.

Videre kan man spørge, om der med det citerede opereres med en slags „konflikternes konstans“. At det partipolitiske konkurrencesystem har brug for uenigheder og konflikter, kan ikke benægtes, men hvad dækker aktuelle konflikter over? Forskellige udgaver af „business as usual“ eller radikalt forskellige bud på samfundets indretning? Og er dannelsen af nye partier nødvendigvis en god indikator på kvalitative ændringer af samfundet, som det også hævdes (22)? I øvrigt kvalificerer JGA modsætnings- og konfliktvinklen, når der peges på, at skal man forstå politisk forandring, er det utilstrækkeligt blot at hæfte sig ved 
politikkens konfliktaspekt, idet politik også er problemløsning (31). Der gives ikke noget forslag til, hvordan dette aspekt af politikken skal begribes i forhold til andre aspekter, men det er interessant at konstatere, at når JGA foreslår internationalisering og postindustrialisme som nye strukturelt forankrede skillelinjer, efterlader det opstillede skema tomme felter i kolonnen „modsætninger“(15).

Hvad specielt angår skillelinjen postindustrialisme som basis for værdipolitikken, skal jeg markere nogle reservationer som udgangspunkt for mit eget forsøg på at opridse en forståelsesramme. Jeg er med på, at først og fremmest miljøproblemerne viser hen til blotlagte krisetendenser i det naturforhold, den industrielle revolution introducerede. Og JGA gør helt rigtigt i at betone, at der her er tale om nogle behov så basale, at det er uden mening i den forbindelse at tale om post-materialisme. Men derfra og til at påstå, at samfundet er blevet post-industrielt, er efter min mening at gå alt for langt. Industrialismens kriterier på rigdom, udvikling og organisering er fortsat i en sådan vigør, at der snarere kan være grund til at tale om superindustrialisme (jf. Loftager 1987). Industrialismens målestok for rigdom par excellence er BNP målt økonomisk vækst (Giarini 1980), og den er fortsat intakt, ligesom den tidligere industrialismekritiske diskussion af grænser for vækst for længst blevet afløst af en bred enighed om „grøn vækst“. Ligeledes tyder den lange og til dels fortsatte forbrugsfest på, at friværdierne har gjort sig nok så stærkt gældende som de postmaterielle værdier, for ikke at nævne den kategoriske status, arbejdsetikken har antaget med aktiveringsparadigmets gennemslag. Superindustrialisme forekommer tillige at være en dækkende betegnelse for "tayloristiske“ resultater af de New Public Management reformer, som skiftende regeringer har ladet den danske offentlige sektor undergå. Disse reformer såvel som aktiveringsrevolutionen i velfærdspolitikken kan siges at udgøre gode eksempler på væsentlige forandringer, der ikke manifesterer sig i det partipolitiske spil og dermed magtens første ansigt, men som er så væsentlige, at det måske er noget, man burde undre sig over.

Imidlertid gør JGA rigtigt i at lægge vægt på en skelnen mellem industrialisme og kapitalisme. Rodes begreberne sammen, som det gøres hos Lipset \& Rokkan (1967) og med dem mange andre, når den traditionelle skillelinje mellem arbejder og arbejdsgiver knyttes til samfundet som industrisamfund, mistes grundlaget for at skelne mellem kapitalistiske og socialistiske industrisamfund. I videre forstand og aktuelt væsentligere drejer det sig om forholdet mellem det moderne samfunds vertikale kapitalistisk-klassemæssige og dets industrialistiske horisontale differentieringer. Netop det er afgørende i det teoriunivers, der nu skal skitseres. Her forventes det, at den horisontale og „funktionelle differentiering“ (Luhmann 1999) får stedse større betydning for samfundets udviklingsdynamik. Dermed sættes samtidig fokus på problemløsningsaspektet af politikken, på identiteten som borger og på demokratiet som deliberativt demokrati.

Til en begyndelse vil jeg med John Dewey foreslå, at

we take our point of departure from the objective fact that ... indirect, extensive, enduring and serious consequences of conjoint and interacting behaviour call a public into existence having a common interest in controlling these consequences (Dewey 1946, 12; 126).

Der er en klar familielighed mellem Deweys pragmatiske grundbetragtning og den klassiske sociologis analyse af transformationen fra det traditionelle til det moderne samfund. Især er der klare paralleller til Durkheims sociologi, og når Deweys anbefalede svar på udfordringerne skal søges $i$,the improvement and conditions of debate, discussion and persuasion“ "(208), er der tale om en slående lighed i forhold til Durkheims betoning af offentlig diskussion og deliberation som forudsætning for varetagelsen af politikkens handlingskoordinerende sociale funktion. Og præcis dette er i henhold til Durkheim politikkens og statens primære, ja, konstitutive opgave (Durkheim 1996).

Udgangspunktet er eksistensen af et såkaldt politisk samfund, dvs. et samfund bestånde af et stort antal grupper, der har brug for en politisk autoritet. Der er netop tale om en funktionel snarere end en institutionel bestemmelse af staten, og dens opgave er ikke alene - jf. Eastons politikdefinition - at kanalisere og koncentrere krav og ønsker fra de forskellige samfundsgrupper

\section{it is ... the organizing centre of the secondary groups themselves. ... its true meaning consists not in exterior action ... but in deliberation, that is, representations ... parallel to that between the muscular system and the nervous system ... the very organ of social thought ... its principal function is to think. (Durkheim 1996, 40-41)}

Dermed introduceres, som det også siges, et element af refleksiv tænkning i det sociale liv. Og med statens udvikling som først og fremmest et "refleksionsorgan“ muliggøres håndteringen af det dynamiske, arbejdsdelte samfunds mere og mere komplekse problemer (Durkheim 1996, 45-46). Med andre ord er der tale om en grundforståelse af samfundsudviklingen som læreproces med politikken som centralt omdrejningspunkt. Svarende hertil definerer Durkheim ikke demokratiet institutionelt, men funktionelt som et spørgsmål om omfanget og karakteren 
af kommunikationen mellem de politiske myndigheder og borgerne (59).

Durkheims fremhævelse af statens væsentlige (og positive) rolle er ikke ensbetydende med en konservativ negligering af individet. Tværtimod er det en afgørende pointe, at stat og individ ,progress in parallel: The stronger, the more active the state becomes, the more the individual increases his liberty. It is the state that sets him free" (Durkheim 1996, 50). Men liberalismens forestillinger om oprindeligt flyvefærdige individer afvises bastant, og det betones, at individet er et historisk produkt af især det moderne samfunds udvikling, ligesom det understreges, hvordan synet på det enkelte menneske har udviklet sig fra noget værdiløst til det mest hellige og ukrænkelige (49).

Dette fremgår også ganske tydeligt $\mathrm{i}$ hovedværket om den sociale arbejdsdeling og den heri indeholdte teori om mekanisk og organisk solidaritet, som efter min opfattelse kan tjene som et vigtigt korrektiv til tidens dominerende værdidiskurs (Durkheim 2000; jf. Loftager 2006) og derfor kort skal omtales. På den ene side synes denne diskurs at referere til en før moderne mekanisk-solidarisk forestilling om, at det samfundsmæssige fællesskab primært beror på fælles værdier og identiteter. På den anden side ignorerer den muligheden af den organiske solidaritet, som ifølge Durkheim vokser eller kan vokse frem i det moderne samfund, og som individet som individ er knyttet til. Hvor solidariteten i traditionelle samfund kun kan vokse i omvendt forhold til personligheden (Durkheim 2000: 139), kan fællesskab og individualitet i det moderne arbejdsdelte samfund vokse på samme tid. Det skyldes, at solidariteten nu ikke primært er baseret på ens værdier, men på de forskelle og funktionelle afhængigheder, der følger med den udstrakte arbejdsdeling. Vi indgår i et organisk, differentieret hele, hvor den gensidige afhængighed vokser med forskellene. Derfor bruger Durkheim betegnelsen organisk om denne form for solidaritet.

Der er dog en basal undtagelse fra den generelle tendens til, at fællesskabet som værdi- og identitetsfællesskab bliver stadigt svagere. Og det er med hensyn til netop individet og dets autonomi og rettigheder. Den generelt voksende tolerance gælder ikke, når det drejer sig om adfærd, der truer eller udviser mangel på respekt for andres individualitet og personlige ukrænkelighed.

Der er rigtignok et sted, hvor den fælles bevidsthed er blevet styrket og præciseret, og det er der, hvor den vedrører individet. I takt med at alle de andre overbevisninger og praksisser antager en mindre og mindre religiøs karakter, bliver individet genstand for en slags religion. Vi har en kult omkring personens værdighed ... (140).
Det moderne samfunds form for fællesskab er dermed ifølge Durkheim et fællesskab, der ikke blot kan rumme, men som danner sig omkring individet.

Der er klare paralleller mellem Durkheims begreb om en moderne organisk form for solidaritet og T.H. Marshalls begreb om medborgerskab (citizenship), som udtrykkeligt modstilles både før-moderne slægtsbaserede fællesskaber og følelsesbetonede, nationalpatriotiske fællesskaber (Marshall 2003, 102). Medborgerskabet er hos Marshall båret oppe af den lige status og identitet, alle borgere opnår i kraft af universelle civile, politiske og sociale rettigheder. Og hvor Marx og den efterfølgende socialistiske tradition påpegede det illusoriske i forestillingen om at virkeliggøre en sådan lige demokratisk borgerstatus inden for rammerne af det kapitalistiske markeds- og klassesamfund, er det hovedsagen for Marshall at vise, at det faktisk er muligt. Ikke mindst kunne de sociale rettigheder som universelle borgerrettigheder og derunder ,retten til en realindkomst, som ikke er afpasset efter indkomstmodtagerens markedsværdi“ (28) erstatte den ejendomsbesiddelse, der tidligere dannede det socialøkonomiske grundlag for rollen og identiteten som demokratisk deltagende borger (jf. Habermas 1975).

Durkheim og Marshall tænker således begge et fællesskab, som ikke står i modsætning til, men forudsætter stærke individer. Den kult om individet, Durkheim ser bryde frem som værdimæssigt tilbehør til den organisk solidaritet, kan ses som udtryk for Marshalls lige status som medborger. Der er tale om en identitet af generel natur, som hæver sig over de partikulære gruppe- og klassetilhørsforhold. Som Durkheim udtrykker det, vil den kollektive (værdi)bevidsthed i det moderne, arbejdsdelte samfund „mere og mere bestå i måder at tænke og føle på, der er meget generelle og ubestemte, og som lader pladsen stå åben for en stigende mangfoldighed af individuelle meningsforskelle“ (Durkheim 2000, 173).

\section{Værdipolitikkens udfordring af det deliberative demokrati}

Som muligt korrektiv til den aktuelle nypolitiske værdidiskurs og dens identitetsbegreb er det herefter centralt at vurdere, om og hvor langt de skitserede politisk-sociologiske teoretiske antagelser og beskrivelser kan påberåbe sig gyldighed. Efter min opfattelse er det ganske langt og så langt, at det må undre, at der kan udvikle sig diskurser og former for politisk praksis ude af takt hermed. Jeg kan her henvise til en mere omfattende analyse af demokratiets danske tilstand, hvor jeg har forsøgt at argumentere for, hvordan både Durkheims og Marshalls teorier i stor udstrækning er blevet bekræftet af hovedstrømmen i nyere dansk politisk-demokratisk historie, men også, at der 
i de seneste årtier har gjort sig modstrømme gældende (Loftager 2004).

Centrale argumenter er i den forbindelse, at det faktisk har vist sig rigtigt, at forholdet mellem stat og individ har udviklet sig som et plus-sums- snarere end et nul-ssumsspil. Ligeledes, at en borgeridentitet og en tilhørende norm om borgerlighed har vundet styrke svarende til Marshalls forventninger og visioner (jf. Loftager 2009). I overensstemmelse hermed er det også væsentligt, at dansk politik over de længere stræk rummer klare elementer af læreproces. Og helt tilbage fra den danske „opinionsstyrede enevælde“ (Seip 1958) kan det iagttages, hvordan et offentligt ræsonnement har gjort sig gældende og dermed kvalificeret billedet af politik som primært aggregering af og konflikt mellem fastlåste interesser, identiteter, ideologier og/eller præferencer. Dansk demokrati har dermed i betydelig grad fungeret i overensstemmelse med den deliberative demokratiforestilling, hvor politiske beslutningers legitimitet væsentligst flyder af offentligt fremsatte og diskuterbare begrundelser snarere end af deres afspejling af vælgernes holdninger og præferencer - sådan som tilfældet er i den såkaldte økonomiske demokratiopfattelse (Downs 1957; jf. Loftager 2004, kap. 2). At den slags idealer også er blevet principielt formuleret i dansk sammenhæng, er Hal Kochs Hvad er demokrati? nok det bedste eksempel på. Tillige er det veldokumenteret, at netop den type demokratiopfattelse typisk angives, når danske folketingsmedlemmer skal gøre rede for deres repræsentationsidealer (Loftager 2004, kap. 6).

På den baggrund er det problematisk at reducere gammel- eller fordelingspolitikken og dens klassekonflikt til essentielt at dreje sig om social tryghed og økonomisk udligning, sådan som det i første omgang fremgår hos JGA. Når „social tryghed og økonomisk udligning“ $i$ anden omgang $i$ en note oversættes til „fuldt medborgerskab“, er det naturligvis i bedre samklang med synspunktet her (Goul Andersen 2007, 16). Det afgørende er at indse, at der også i interessepolitikkens glansperiode var langt mere på spil end økonomisk-tekniske fordelingsspørgsmål af kvantitativ art. Nok kan det siges, at periodens største „problem“ var udvekslingen og kampen mellem de kapitalistisk definerede klasseinteresser, men det handlede essentielt om magt og demokrati og ikke mindst om alles anerkendelse som medborgere som problemets løsning. ${ }^{4}$ Med andre ord drejede det sig også om identitet og altså netop den form for borgeridentitet, der kan understøtte det deliberative demokrati. Dens generelle og ubestemte karakter muliggør, at uenigheder og konflikter om det mylder af komplekse problemer, der er karakteristisk for funktionelt differentierede samfund, kan antage en saglig, ikke personlig og dermed fredelig og produktiv karakter.
Det er i lyset heraf, at jeg finder den værdipolitiske diskurs problematisk. Ikke alene portrætterer den værdiog identitetsproblematikken som noget nyt. Den trækker også opmærksomheden væk fra politikkens problemløsningsaspekt og den tilhørende borgeridentitet. Selve talen om værdier og identiteter som politikkens essens peger i retning af beslutninger snarere end begrundelser. Teoretisk er det markant formuleret hos føromtalte Carl Schmitt, men vore dages poststrukturalister bevæger sig i samme boldgade, og megen mainstream statskundskab gør det for så vidt også. Nemlig i form af den der herskende vardirelativisme og dens påståede logiske kløft mellem er, som videnskabens og rationalitetens gebet, og bør som politikkens felt, hvor de subjektivt besluttede værdier, præferencer og identiteter råder (Rasmussen 1972, 34-35).

Indvandrerdebatten udgør nok det aktuelt mest prægnante eksempel på den form for værdipolitisk diskurs. I bogstavelig forstand opererer den åbenlyst med venfjende figuren - er du ,indvandrervenlig“ "eller ,indvandrerfjendtlig"? Og dermed underforstås, at hele denne problematik kan reduceres til et spørgsmål om beslutning om sådanne værdier og holdninger, ja, om hvem man er og vil være. Men kan den det? Og hvilken mening giver det at spørge til folks fjendtlighed/venlighed til indvandrere i al almindelighed? Man kan naturligvis synes mere eller mindre om for eksempel denne eller hin kulturelt bestemte norm eller praksis, ligesom det kan være meningsfuldt at sige, om man foretrækker indvandring eller ej, men venlighed eller fjendtlighed over for en gruppe mennesker, der alene er defineret som indvandrere, ser ud som en mystifikation. Og i forhold til deliberativt demokrati er problemet, at en debat, der er til at blive klogere af, dermed sander til eller aldrig kommer i gang. I henhold til det her skitserede perspektiv må det af indlysende grunde foretrækkes, at værdidommene lægges til side, og opmærksomheden i stedet koncentreres om at få en sådan sags mange og komplicerede aspekter belyst så godt som muligt, før der drages politiske konklusioner.

Men, kunne en indvending lyde, hvad nu hvis det beviseligt er sådan, at det i væsentlig grad er identitet og identifikation snarere end „evidens“ (jf. Lippert-Rasmussen 2009), der er bestemmende for vælgernes synspunkter? Og det synes faktisk at være tilfældet. Således har Rune Slothuus dokumenteret, at de synspunkter, vælgerne danner i forhold til konkrete politikforslag, i betragtelig udstrækning påvirkes af, hvilket parti der står bag forslaget (Slothuus 2009). Identitetsfaktorens væsentlige betydning for holdningerne til „,ærdipolitikken“ er på linje hermed indikeret af Rune Stubagers påvisning af den betydelige rolle, uddannelse her spiller (Stubager 2009).

Først er der grund til et par kvalificerende bemærkninger. Således må den antydede dikotomi mellem identi- 
tet og evidens modereres, idet også evidensorienterede og -motiverede vælgere kan antages at benytte sig af (blandt andet) politiske partier som pejlemærker og specielt, naturligvis, på områder, de måske hverken har megen viden om eller faste holdninger til. ${ }^{5}$ Det vil være i god overensstemmelse med identiteten som borger. I den forbindelse argumenterer Slothuus for, at partierne i højere grad kan og måske også bør påtage sig rollen som opinionsledere og bidrage til, at holdningsdannelsen kommer til at hvile på gode argumenter og principielle overvejelser. Det forudsætter dog, at partierne ikke kopierer hinandens politik, og at konflikterne ikke reduceres til taktik og personer (Slothuus 2009, 37). Om det så er en realistisk forudsætning skal berøres nedenfor.

Dernæst kunne spørges til det nærmere forhold mellem „identitet“ og „evidens“ i befolkningens holdninger på forskellige områder - for eksempel og eksemplarisk indvandrerfeltet. Her har debatten som nævnt været præget af en identitetspolitisk ven-fjende retorik, men at dømme efter forskningen på feltet indgår der i holdningsdannelsen også pragmatiske evidensbetragtninger i betydelig grad (Nielsen 2007; Thomsen 2006). I forlængelse heraf kunne spørges til den nærmere karakter af de identiteter, der er i spil. Jeg skal ikke forsøge at give et svar, men blot anføre, at det i henhold til det her anlagte teoretiske perspektiv naturligvis gør stor forskel, om der refereres til gruppeidentiteter eller til identiteten som borger. Til eksempel og groft sagt: Afspejler den eksisterende „fiendtlighed“ mod eller ,intolerance“ over for indvandrere en anakronistisk, nationalistisk og evt. racistisk grundholdning, eller bunder den i iagttagelse af alvorlige sociale problemer og kulturelle praksisser i strid med tilkæmpede demokratiske rettigheder og idealer?

Også med disse reservationer in mente kan man imidlertid undre sig over, at politikkens identitetsdimension er kommet så meget mere i forgrunden end problemløsningsdimensionen. Om ikke andet kan det tages som en påmindelse om, hvor svært det kan være at fastholde den skelnen mellem bolden og manden, der er essentiel i det deliberativt fungerende demokrati. Og det er jo heller ikke svært at komme i tanke om gruopvækkende eksempler à la tidligere Jugoslavien på, hvad der kan ske, når identitetskortet for alvor trækkes. Her skal der imidlertid hverken fremmanes skrækscenarier eller blot udstikkes forfaldshypoteser. I stedet skal jeg kort skitsere, hvordan den anvendte sociologiske tilgang kan bidrage med en forklaring af det teoretisk set uventede. Og atter kommer spørgsmålet om identitet eller mangel på samme i centrum.

Grundpåstanden har været, at der med den voksende arbejdsdeling og specialisering opstår et stigende behov for deliberativt demokratisk koordinering og samordning.
Det synes da også at være sket i en vis udstrækning i den danske sammenhæng, og for så vidt der samtidig er sket en svækkelse og/eller inddæmning af klassekonflikten og klasseidentiteten, kunne man umiddelbart forestille sig, at det ville berede vejen for en fortsat og endnu mere udtalt realisering af borgeridentiteten og en virkningsfuld offentlig diskussion. Når de politiske partier har mistet deres tidligere klasseforankring og binding til ideologiske læresætninger, kunne man formode, at de bedre ville være i stand til at indgå i fordomsfri diskussioner med hinanden til gavn for det offentlige ræsonnement og de fælles politiske løsninger (jf. Loftager 2004, kap. 9).

Men den voksende enighed om væsentlige spørgsmål som velfærdsstat, markedsøkonomi, forsvar mv. synes paradoksalt nok ikke at have gjort politikken mere ræsonnabel. Og som jeg ser det, må det i høj grad tilskrives konkurrencemomentet i det demokratiske system. Konkurrencen om stemmerne og magten forudsætter synlighed og forskel og dermed uenighed. Og er den der ikke, må den skabes med en bestandig opskruning af politikkens taktiske momenter som resultat. Nogle vil sige, at politikken derved åbenbarer sit sande væsen - kampen om magten. Og tilhængere af den økonomiske demokratiforestilling kan tage udviklingen til indtægt for forestillingens realisme. Udviklingen synes stadigt stærkere at bekræfte Downs' berømte dictum: „parties formulate politics in order to win elections rather than win elections in order to formulate politics" (Downs 1957, 28). Men i det her anlagte perspektiv må i stedet iagttages, hvordan politikkens konkurrenceelement snarere end at fremme, synes at svække dens problemløsningsrationale.

På den baggrund kan man også spørge til realismen i Rune Slothuus' forhåbninger om partiernes rolle som opinionsledere. Hvor sandsynligt er det, at partierne vil indstille kopieringen af hinandens politik, lægge mindre vægt på taktikken og lade konflikterne dreje sig om substansen snarere end personer som forudsætning for, at holdningsdannelsen kommer til at hvile på gode argumenter og principielle overvejelser? Alternativt kunne man spørge om, hvad der faktisk kunne afstedkomme en bevægelse i den retning. Det spørgsmål skal afslutningsvis kort berøres.

\section{Afsluttende: diskurs og praksis}

Hvad kunne bidrage til, at de politiske partier begyndte at interessere sig mere for substansen end spillet om magten - bolden snarere end manden? Som problemet her er skitseret, må det forstås sociologisk snarere end psykologisk, om end der nok kan iagttages relevante forskelle i den måde, hvorpå partier og repræsentanter fungerer som opinionsledere. Og i tråd med denne artikels tema kunne interessen blandt andet rette sig imod det diskursive ni- 
veau, hvor aktør og struktur mødes. Således kunne man til en begyndelse overveje hensigtsmæssigheden af tidens dominerende værdipolitiske diskurs. Ja, alene det at rejse spørgsmål om partiernes uudnyttede potentiale som opinionsledere overskrider allerede denne diskurs, idet det snarere synes at referere til det aspekt af politik som samfundsmæssig problemløsning/håndtering, jeg har søgt at indfange sociologisk og koble sammen med demokratiet som deliberativt demokrati og identiteten som borger.

Man kunne naturligvis også overveje, om ændringer af det eksisterende institutionelle „set-up“ kunne medvirke til at løse „problemet“. Måske er det ikke så underligt, at politiske institutioner, der er rundet af samfundsmæssige betingelser markant forskelligt fra de nugældende, kan komme ud i funktionsproblemer, og at det kan være et åbent spørgsmål, hvilke repræsentationsformer, valgmåder, forvaltningstyper etc. der i dag ville være at foretrække (jf. Loftager 2004, kap. 9). Forudsætningen for at komme i gang med den slags overvejelser er imidlertid, at hensigtsmæssigheden af den aktuelt dominerende værdipolitiske forståelsesramme både tematiseres og problematiseres.

\section{Referencer}

Althaus, S 2006 'False Starts, Dead Ends, and New Opportunities in Public Opinion Research', Critical Review, vol. 18, no. 1-3, pp. 75-104.

Bacrach, P \& M Baratz 'Two Faces of Power', The American Political Science Review, vol. 56, no. 4, pp. 947-952.

Barber BR 1984 Strong Democracy: Participatory Democracy for a New Age, University of California Press, Berkeley.

Borre, O 2003 'To konfliktdimensioner', i J Goul Andersen m.fl. (red.) Politisk forandring. Verdipolitik og nye skillelinjer ved folketingsvalget 2001, Systime Academica, Århus.

Dewey, J 1946 The Public and its Problems, Gateways Books, Chicago.

Downs, A 1957 An Economic Theory of Democracy, Harper Collins Publication, New York.

Durkheim, É 2000 Om den sociale arbejdsdeling, Hans Reitzels Forlag, København.

Durkheim, É 1996 'The Concept of the State', i A Giddens (red.), Durkheim on Politics \& the State, Polity Press, Cambridge.

Easton, D 1953 The Political System, The University of Chicago Press, Chicago.

Giarini, O 1980 Dialogue on Wealth and Welfare, Pergamon, Oxford.

Goul Andersen, J 2007 'Samfundskonflikter, partier i bevægelse og vælgere medomtanke: Rids af en generel teoretisk ramme', i J Goul Andersen m.fl. (red.), Det nye politiske landskab. Folketingsvalget 2005 i perspektiv, Academica, Århus.

Goul Andersen, J m.fl. (red.) 2007 Det nye politiske landskab. Folketingsvalget 2005 i perspektiv, Academica, Århus.

Goul Andersen, J \& O Borre (red.) 2003 Politisk forandring. Vardipolitik og skillelinjer ved folketingsvalget 2001, Systime, Århus.

Habermas, J 1975 Borgerlig Offentlighet, Oslo: Gyldendal Norsk Forlag.

Jyllandsposten 12-08-09.

Kaspersen, LB \& J Loftager 2009 'Introduktion', i LB Kaspersen \& J Loftager (red.), Klassisk og moderne politisk teori, Hans Reitzels Forlag, København.

Koch, H 1945/1991. Hvad er demokrati?, Gyldendal, København.
Larsen, LB \& CB Laustsen 2009 'Carl Schmitt', LB Kaspersen \& J Loftager (red.), Klassisk og moderne politisk teori, Hans Reitzels Forlag, København.

Lippert-Rasmussen, K 2009 'Men nu siger du jo det same som Pia Kjærsgaard': Om meninger, indhold og identitet, i J Blom-Hansen \& J Elklit (red.), Perspektiver på politik. Bidrag til samfundsdebatten, Academica, Århus.

Lipset, SM \& S Rokkan 1967 'Cleavage Structure, Party Systems and Voter Alignments: An Introduction', i SM Lipset \& S Rokkan (eds.), Party Systems and Voter Alignments, Free Press, New York.

Loftager, J 2009 'Marx og socialismen', i LB Kaspersen \& J Loftager (red.), Klassisk og moderne politisk teori, Hans Reitzels Forlag, København.

Loftager, J 2009 'Den underkendte borger', i J Blom-Hansen \& J Elklit (red.), Perspektiver på politik. Bidrag til samfundsdebatten, Academica, Århus.

Loftager,J 2006 'Værdifri samfundskritik-teknokrati eller demokrati?', i HK Nielsen \& F Horn (red.), Kritik som deltagelse, Klim, Århus.

Loftager, J 2004 Politisk offentlighed og demokrati i Danmark, Aarhus Universitetsforlag, Århus.

Loftager, J 1987 'Et postindustrielt samfund?', H Fink m.fl. (red.), Grenser for rationalitet, Aarhus Universitetsforlag, Århus.

Luhmann, N 1999 Sociale systemer, Hans Reitzels Forlag, København.

Lukes, S 1983 Power - A Radical View, London: Macmillan.

Marshall, TH 2003 Medborgerskab og social klasse, Hans Reitzels Forlag, København.

Marx, K 1970-1972 Kapitalen, Rhodos, København.

Nielsen, HJ 2007 'Hvilken slags indvandrere ønsker man?', i J Goul Andersen m.fl. (red.), Det nye politiske landskab. Folketingsvalget 2005 i perspektiv, Academica, Århus.

Rasmussen, E 1972 Komparativ Politik I, Gyldendal, København.

Rostbøll, CF 2009 'Hannah Arendt', i LB Kaspersen \& J Loftager (red.), Klassisk og moderne politisk teori, Hans Reitzels Forlag, København.

Seip, JA 1958 'Teorien om den opinionsstyrede enevælde', Norsk historisk tidsskrift, vol. 38.

Slothuus, R 2009 'Behøver politikerne løbe efter vælgernes holdninger?', i J Blom-Hansen \& J Elklit (red.), Perspektiver på politik. Bidrag til samfundsdebatten, Academica, Århus.

Spragens, TA 1981 The Irony of Liberal Reason, Chicago, Chicago University Press.

Stubager, R 2009 'Education-based group identity and consciousness in the authoritarian-libertarian value conflict', European Journal of Political Research, vol. 48, nr. 2.

Thomsen, JPF 2008 Politik $i$ det moderne samfund, Hans Reitzels Forlag, København.

Thomsen, JPF 2006 Konflikten om de nye danskere, Akademisk Forlag, København.

Van Deth, JW \& E Scarbrough (eds.) 1998. The Impact of Values, Oxford University Press, Oxford.

Warren, ME 1996 'Deliberative Democracy and Authority', American Political Science Review, vol. 90, no. 1, pp. 46-60.

\section{Noter:}

1. Jf. her Scott Althaus, som har gjort opmærksom på, hvordan public opinion-forskningen lider af manglen på en artikuleret demokratiteori, og som argumenterer for, at „research on the nature of public opinion appears politically sterile when it is isolated from larger questions about what public opinion is supposed to do for democracies"(Althaus 2006, 98). 
2. Jeg støtter mig i dette afsnit til Kaspersen \& Loftager (2009), og nogle formuleringer stammer herfra.

3. Forstået bredt som også problemhåndtering. Ofte vil politikken være optaget af samme type problemer over tid.

4. Eller foreløbige løsning, for historien rummer naturligvis ingen garantier for, at den lige status som borger vedvarende vil kunne tjene som formidler mellem kapitalisme og demokrati (jf. Loftager 2009)
5. I den forbindelse er det en vigtig pointe, at deliberativt demokrati ikke opererer med et ideal om alles (direkte), maksimale deltagelse (jf. Warren 1996). 